\title{
The Effect of Nuhonni-Tulaar Rheumatic Exercise on Pain Reduction of Knee Osteoarthritis Patients
}

\author{
Ferius Soewito ${ }^{1}$, Siti Annisa Nuhonni ${ }^{1}$, Elida Ilyas ${ }^{1}$, Muchtaruddin Mansyur $^{2}$, Angela BM Tulaar ${ }^{1}$ \\ 1 Department of Physical Medicine and Rehabilitation, Faculty of Medicine - University of Indonesia, \\ Jakarta \\ 2 Department of Community Medicine, Faculty of Medicine - University of Indonesia, Jakarta \\ (This Research Article has been presented in Free Paper session of $3^{\text {rd }}$ Asia-Oceania Conference of \\ Physical and Rehabilitation Medicine, $20^{\text {th }}-23^{\text {rd }}$ May 2012)
}

\begin{abstract}
Objectives: Knee osteoarthritis patient has the risk for ambulation disability as a result of knee pain. Nuhonni-Tulaar rheumatic exercise was designed to prevent complications of rheumatic diseases including knee osteoarthritis. The purpose of this study is to investigate the effectivity of NuhonniTulaar rheumatic exercise to reduce pain of knee osteoarthritis patient.

Methods: Twenty two subjects did the rheumatic exercise thrice a week in the gymnasium of medical rehabilitation department Cipto Mangunkusumo hospital. Twenty other subjects, the control group, did the standard hamstring stretching exercise at home. Each group performed the exercise for 8 weeks. Pain was measured using Visual Analog Scale (VAS) each week and analyzed before and after the intervention.

Results: After 8 weeks VAS was reduced 1.5 in the intervention group while in the control group the reduction was 0.9. VAS was then transformed into no pain, mild pain, moderate pain and severe pain. VAS was significantly reduced in the intervention group $(\mathrm{p}=0.002)$ but not in the control group $(\mathrm{p}=0.059)$. VAS changes between the two groups was significantly different $(\mathrm{p}=0.004)$.

Conclusions: Rheumatic exercise has greater benefit in reducing pain than standard stretching exercise. Warming up, core exercise II and cooling down is safe and comfortable for knee osteoarthritis patient with grade I-II Kellgren Lawrence radiographic grading.
\end{abstract}

Keywords: Nuhonni-Tulaar Rheumatic exercise, Knee osteoarthritis, Visual Analog Scale.

\section{INTRODUCTION}

Osteoarthritis (OA) is the most frequent chronic joint disease in the community. ${ }^{1}$ The chronicity and progresivity of OA caused high socio-economic burden that World Health Organization (WHO) announced OA as the $10^{\text {th }}$ highest cause of non-fatal burden on year $1990 .^{2}$ About 100.000 people in United States can

Received in March 2013 and accepted for published in April 2013.

Correspondence email: Ferius Soewito, ferius_md@ yahoo.com not walk independently from bed to bathroom because of knee OA. In Indonesia, about 1-2 million elderly suffer from disability caused by $\mathrm{OA}^{3}$

Knee OA has the highest disability risk related with ambulation among $\mathrm{OA}$ at the other part of the body. ${ }^{4}$ Knee OA will result in range of motion limitation and muscle weakness. ${ }^{5}$ The range of motion limitation is primarily occur on extension movement. Extension limitation is resulted from hamstring muscle shortening, occuring after prolonged flexion position which is maintained when the OA patient felt pain. 
Further pain is then generated by hamstring shortening.

It is now widely accepted that therapeutic exercise becomes the first line modality for OA management. Exercise was even recommended before the drug was given. ${ }^{6}$ Exercise has been reported to have positive effects on periarticular muscles strengthening and preventing biomechanic abnormalities. Exercise was also reported to decrease pain at joints and tendons. ${ }^{5,6}$

On 2007, Nuhonni and Tulaar ${ }^{7}$ from Physical Medicine and Rehabilitation Department Cipto Mangunkusumo Hospital Jakarta have designed exercises for rheumatic patients, including knee OA. The exercise is then known as Rheumatic Exercise.

The effect of rheumatic exercise on the clinical symptoms and functional status of OA patients has not been studied. The aim of this research is to investigate whether rheumatic exercise can reduce the pain of knee OA patients.

\section{METHODS}

This research is a part of thesis research by Soewito done from August through December $2010{ }^{8}$ Forty-two subjects were recruited from musculoskeletal clinic Physical Medicine and Rehabilitation department Dr Cipto Mangunkusumo hospital. The inclusion criterias are patients with knee OA diagnosed using clinical-radiographical diagnostic criteria of American College of Rheumatology, radiographic grade was I and II according to Kellgren Lawrence Radiographic Grading Criteria, age ranges from 35 to 70 years, male and female, no deformity on lower extremity, can walk without gait aids, can perform exercise in standing position and agree to participate in the study. The subjects would not be involved in this study if he or she had neuromuscular, cardiopulmonar, psychiatric or cognitive disturbance. Subjects will be considered dropped out if he or she can not continue doing the exercise for medical and non medical reason, or if he or she can continue the exercise but did not want to continue. The Kellgren Lawrence Radiographic criteria can be seen in table 1 .

Table 1. Kellgren Lawrence Radiographic Criteria9

\begin{tabular}{cc}
\hline Grade & Criteria \\
\hline 0 & Normal \\
1 & Small Osteofit \\
2 & Large Osteofit without joint space narrowing \\
3 & Definite Osteofit with joint space narrowing \\
4 & Definite osteofit with joint space narrowing and subchondral sclerosis \\
\hline
\end{tabular}

The subjects were then allocated into rheumatic exercise group and control group. The allocation was made based on subject preference, not random. After the allocation, there were 22 subjects in the rheumatic exercise group and 20 subjects in the control group.

The rheumatic exercise group did the rheumatic exercise in the gymnastic room Physical Medicine and Rehabilitation Cipto Mangunkusumo Hospital for 8 weeks, thrice a week. The exercise was lead by an intructor who first explained about the exercise and taught the subjects how to perform the movement correctly. The rheumatic exercise that was performed was the warming-up, core-exercise
II, and the cooling-down. It consists of aerobic, strengthening, range of motion and stretching exercise of muscles from trunk, upper and lower extremities.

The control group was taught the standard home program hamstring stretching exercise. The hamstring stretching exercise was performed with one hip flexed maximally while the knee was fully extended. The maximal flexion of the hip was then maintained for five counts (approximately 8 seconds). The movement was repeated 5 times at the same lower extremity with 3 seconds rest between movements. The exercise was also performed on other extremity. The hamstring exercise was done at 
home for 8 weeks, thrice a week, each exercise performed was written down in a logbook. The meeting was conducted every week to check the logbook, had the exercise been performed correctly and if there were any problems while doing the exercise.

The pain intensity was monitored using Visual Analog Scale (VAS). For the rheumatic exercise group, the VAS was asked before and after each exercise. VAS was asked in each weekly meeting for subjects from the control group. Comfortability was measured using Visual Analog Comfort Scale (VACS) only for rheumatic exercise group at the end of exercise. VACS is similar to VAS, using a ten centimeter line that represent the comfortability grade. The zero score represents uncomfortable, the tenth score represents maximal comfort. Complaints were recorded before each exercise for the rheumatic exercise group and every week for the control group. Vital signs were monitored before and after each exercise session. At the end of the program, compliance from both groups was recorded.

All data were entered and analyzed using
SPSS 10.0. Baseline data, such as age, sex, body mass index, activity, Kellgren Lawrence grading, baseline chair sit and reach test and VAS were compared between groups and tested for the homogeneity. Compliance was also analyzed for the homogeneity between both groups. Compliance was classified according to Standar Pelayanan Minimal RS published by Dirjen Bina Pelayanan Medik Departemen Kesehatan tahun 2008, bab IX Rehabilitasi Medik ${ }^{10}$ as the same or below $50 \%$ and above $50 \%$.

Although VAS was recorded from each exercise session, only VAS before-after the program that was analyzed. Any increased of VAS while exercising was recorded. VAS changes before and after the program, and between groups was also calculated. VAS was then transformed into ordinal data consist of no pain $(\mathrm{VAS}=0)$, mild pain (VAS=1-3), moderate pain $(\mathrm{VAS}=4-7)$ and severe pain $(\mathrm{VAS}=8-10)$ and analyzed accordingly.

\section{RESULTS}

Baseline characteristics can be seen in table 2 .

Table 2. Baseline Characteristics of the Subjects

\begin{tabular}{|c|c|c|c|}
\hline Variable & Intervention Group $(\mathrm{n}=\mathbf{2 2})$ & Control Group $(n=20)$ & $p$ \\
\hline Age(year) & $53.8(8.6)$ & $57.3(9.0)$ & $0.215^{*}$ \\
\hline Sex: & & & $0.732^{\mathrm{t}}$ \\
\hline Male & $4.5 \%$ & $5 \%$ & \\
\hline Female & $95.5 \%$ & $95 \%$ & \\
\hline Body Mass Index $\left(\mathrm{Kg} / \mathrm{m}^{2}\right)$ & $26.3(4.3)$ & $25,8(3,9)$ & $0.690 *$ \\
\hline Activity $^{\mathrm{a}}$ & & & $0.062^{ \pm}$ \\
\hline Passive & $9.1 \%$ & $35 \%$ & \\
\hline Active & $90.9 \%$ & $65 \%$ & \\
\hline \multicolumn{4}{|l|}{ Kellgren Lawrence grading } \\
\hline KL I & $63.6 \%$ & $75 \%$ & \\
\hline KL II & $36.36 \%$ & $25 \%$ & $0.426^{\mathrm{t}}$ \\
\hline \multicolumn{4}{|l|}{ VAS } \\
\hline No pain $(\mathrm{VAS}=0)$ & $31.8 \%$ & $15 \%$ & \\
\hline Mild $(\mathrm{VAS}=1-3 \mathrm{~cm})$ & $27.3 \%$ & $25 \%$ & $0.166 * *$ \\
\hline Moderate $(\mathrm{VAS}=4-7 \mathrm{~cm})$ & $40.9 \%$ & $60 \%$ & \\
\hline Severe $($ VAS $=8-10 \mathrm{~cm})$ & $0 \%$ & $0 \%$ & \\
\hline $\begin{array}{l}\text { - Subjects were considere } \\
\text { main activity done in a c } \\
\text { Subjects were considere } \\
\text { was the main activity do }\end{array}$ & $\begin{array}{l}\text { assive if sitting was the } \\
\text { ctive if standing or walking } \\
\text { in a day, or when sitting, }\end{array}$ & $\begin{array}{l}\text { standing and walkin } \\
\text { * Using paired T test } \\
\text { * Using chi square test } \\
\text { ** Using Mann Whitney test }\end{array}$ & done in a day. \\
\hline
\end{tabular}


The pain intensity was reduced on both groups after 8 weeks of intervention. In the rheumatic exercise group the VAS was reduced 1.5 while in the control group the reduction was 0.9. From the rheumatic exercise group, there was no report of increase pain, while from the control group, one patient report the pain increase from $\mathrm{VAS}=0$ to $\mathrm{VAS}=1$. Table 3 shows the result of chair sit and reach test measurement, VAS and compliance between groups.

Table 3. VAS Before and After Study and Compliance of Both Groups

\begin{tabular}{|c|c|c|c|c|}
\hline & Before & After & $\begin{array}{l}\text { P value before } \\
\text { and after }\end{array}$ & $\begin{array}{c}\text { P value between } \\
\text { groups }\end{array}$ \\
\hline \multicolumn{5}{|l|}{ VAS } \\
\hline \multicolumn{5}{|l|}{$\begin{array}{l}\text { Rheumatic } \\
\text { exercise group }\end{array}$} \\
\hline $\begin{array}{l}\text { No pain } \\
\text { (VAS=0) }\end{array}$ & $31.8 \%$ & $40.9 \%$ & $0.002 * *$ & \\
\hline $\begin{array}{l}\text { Mild pain } \\
(\text { VAS=1-3) }\end{array}$ & $27.3 \%$ & $59.1 \%$ & & \\
\hline $\begin{array}{l}\text { Moderate pain } \\
\text { (VAS=4-7) }\end{array}$ & $40.9 \%$ & $0 \%$ & & \\
\hline $\begin{array}{l}\text { Severe pain } \\
(\mathrm{VAS}=8-10)\end{array}$ & $0 \%$ & $0 \%$ & & $0.004 * *$ \\
\hline \multicolumn{5}{|l|}{ Control group } \\
\hline $\begin{array}{l}\text { No pain } \\
\text { (VAS=0) }\end{array}$ & $15 \%$ & $15 \%$ & & \\
\hline $\begin{array}{l}\text { Mild pain } \\
\text { (VAS=1-3) }\end{array}$ & $25 \%$ & $50 \%$ & & \\
\hline $\begin{array}{l}\text { Moderate pain } \\
(\mathrm{VAS}=4-7)\end{array}$ & $60 \%$ & $35 \%$ & $0.059 * *$ & \\
\hline $\begin{array}{l}\text { Severe pain } \\
(\mathrm{VAS}=8-10)\end{array}$ & $0 \%$ & $0 \%$ & & \\
\hline $\begin{array}{l}\text { Compliance } \\
\text { Rheumatic exercise } \\
\text { group }\end{array}$ & & $18,2 \%$ & & \\
\hline$\leq 50 \%$ & $18,2 \%$ & & & \\
\hline$>50 \%$ & $81,8 \%$ & & & $0,065^{ \pm}$ \\
\hline \multicolumn{5}{|l|}{ Control group } \\
\hline$\leq 50 \%$ & $0 \%$ & & & \\
\hline$>50 \%$ & $100 \%$ & & & \\
\hline
\end{tabular}

There was noreport ofacutemusculoskeletal and cardiorespiration complications during and after the exercise. Semi-quantitatively, using Visual Analog Comfort Scale, the comfortability of rheumatic exercise was $8.1( \pm 1.7)$.

\section{DISCUSSION}

The limitation of this study is the non random allocation. The allocation of subjects was based on subjects preference. Although the random allocation was not done in this study, statistic analysis has showed the equal distribution of identified confounding factors between groups. Yet, the unidentified confounding factors may still affect the result of this study.

The researchers have not measured muscle strength and aerobic capacity of the subjects as well. Research that used random allocation and analyzed the muscle strengthening, aerobic capacity, flexibility, pain and other factors comprehensively may provide more thorough 
explanation of Nuhonni-Tulaar rheumatic exercise.

The diagnostic criteriathat is used for this study is clinical-radiographic criteria according to American College on Rheumatology. ${ }^{11}$ The clinical-radiographic criteria is used in this study because it has good sensitivity as well as good specificity (sensitivity $91 \%$ and specificity $86 \%$ ).

This study investigates the warming up, core exercise II, and cooling down section of Nuhonni-Tulaar rheumatic exercise. NuhonniTulaar rheumatic exercise consists of four sections: ${ }^{7}$ warming up, core exercise I, core exercise II and cooling down. The core exercise I is meant to increase cardiorespiratory capacity of patients with rheumatic diseases. The joint flexibility and muscle strength is expected to be maintained and improved with core exercise II. Thus the core exercise II is more relevant to be used in this study. Cardiorespiratory exercise is thought to be sufficiently provided by the warming up section.

Because this is the first study that measured the effect of rheumatic exercise on pain reduction of osteoarthritis patients, a preliminary study using twenty subjects as the minimal sample size of each group was conducted. This study obtained 22 subjects for the rheumatic exercise group and 20 subjects in the control group. After the clinical value had been obtained, power was calculated. The power of this study is between $70-80 \%$. It is then considered sufficient and the result of this study can be used as a real study.

The effect of exercise has been reported by numbers of study. Petrella et al. ${ }^{12}$ made a systematic review of 23 randomized clinical trials and found that exercise can reduce pain and improve walking ability of knee osteoarthritis patients. Roddy et al. ${ }^{13}$ found three randomized clinical trials which reported the effect of aerobic exercise in decreasing pain and 16 randomized clinical trials of the effect of strength training.

Within 8 weeks exercise, the pain was found increase only in one subject from the control group. The pain was increased from 0 to 1. From the rheumatic exercise group, no subject reported of increased pain. The mean VAS was found reduced on both groups after 8 weeks of exercise. After VAS was classified into no pain, mild pain, moderate pain and severe pain, the mean pain was found to reduce significantly on rheumatic exercise group but not on the control group. After the change between groups was analyzed, VAS on the rheumatic exercise was significantly lower than the control group (see table 3).

Although the VAS was not significantly reduced on the control group, clinically the VAS was also decreased after 8 weeks standard hamstring stretching exercise. Exercise has been reported to decrease pain. The underlying mechanism has not been fully understood but it may involve endogen opiate stimulation and non nociseptive input facilitation. ${ }^{14}$ Stretching exercise has been theorized to decrease pain as well. Shortening of musculotendinous structure of hamstring muscle because of osteoarthritis will inhibit the extension movement and cause the energy needed increase. The shortening will also cause the biomechanic abnormality of lumbal, hip and knee. ${ }^{15}$ Though theoretically stretching exercise will reduce pain, this study revealed that stretching exercise alone is not sufficient in reducing pain. The pain caused by osteoarthritis may be resulted from various factors, not only from soft tissue shortening.

Effect of rheumatic exercise on pain management is greater statistically $(p=0.004)$ and clinically than standard stretching exercise. Rheumatic exercise is a combination of aerobic, stretching and strengthening exercise. The strengthening training of Quadriceps femoris muscle has been reported by Tulaar ${ }^{16}$ to reduce the catabolism process of osteoarthritis and increase the anabolism process of knee joint cartilage. MMP-3, the catabolic enzyme of joint cartilage, is reduced and TIMP as the inhibitor of MMP-3 has been found increase after Quadriceps femoris strength training.

\section{CONCLUSIONS}

Rheumatic exercise has greater benefit in reducing pain than standard stretching exercise. Warming up, core exercise II and cooling down is safe and comfortable for knee osteoarthritis patient with grade I-II Kellgren Lawrence 
radiographic grading. More research should be conducted to investigate comprehensively the effect of strengthening, aerobic capacity with its relation with flexibility and pain of patient with knee osteoarthritis. The safety of rheumatic exercise on patient with knee osteoarthritis grade III-IV Kellgren Lawrence should also be investigated.

\section{REFERENCES}

1. Bone KW, Javaid K, Arden N, Cooper C. Regular review: Medical management of osteoarthritis. BMJ. 2000;321;936-40.

2. Symmons D, Mathers C, Pfleger B. Global burden of osteoarthritis in the year 2000 . Global burden of disease 2000. World Health Organization.

3. Soeroso $\mathrm{J}$, Isbagio $\mathrm{H}$, Kalim $\mathrm{H}$, Broto R, Pramudiyo R. Osteoarthritis. Dalam: Sudoyo A, Setiyohadi B, Alwi I, Simadibrata M, Setiati S, editor. Buku ajar ilmu penyakit dalam. 4th edition. Jakarta: Pusat Penerbitan Departemen Ilmu Penyakit Dalam Fakultas Kedokteran Universitas Indonesia; 2006. p.1205-13.

4. Provenzano DA, Levin M. Chronic pain syndromes: how to break the cycle, part1. Medical Progress. 2009 February;36(2):65-9.

5. Stitik TDP, Foye PM, Stiskal D, Nadler R. Osteoarthritis. Dalam: DeLisa JA, Gans BM, Walsh NE, Bockenek WL, Frontera WR, Geiringer SR, editor. Physical medicine and rehabilitation, principles and practice. 4th ed. Philadelphia: Lippincott Williams and Wilkins; 2005. p.765-87.

6. Hunter DJ, Felson DT. Osteoarthritis. BMJ 2006;332;639-42.
7. Nuhonni SA, Tular ABM. Pengantar video senam rematik. Jakarta:Pfizer;2008

8. Soewito F. Efektivitas senam rematik terhadap fleksibilitas hamstring penderita osteoartritis lutut [thesis]. Jakarta: Universitas Indonesia; 2010.

9. Kellgren JH and Lawrence JS. Annals of the Rheumatic Diseases. 1957;16:494-5

10. Dirjen Bina Pelayanan Medik Departemen Kesehatan RI. Standar Pelayanan Minimal RS. Departemen Kesehatan; 2008.

11. Klippel JH, Stone JH, Crofford LJ, White PH, editors. Appendix 1: Criteria for the classification and diagnosis of the rheumatic diseases. Primer on the rheumatic diseases. $13^{\text {th }}$ ed. USA: Springer Science+business media; 2008. p.674

12. Petrella RJ. Is exercise effective treatment for osteoarthritis of the knee? Br J Sports Med. 2000; 34: 326-31.

13. Roddy E, Zhang W, Doherty M, Arden NK, Barlow J, Birrell F, et al. Evidence-based recommendations for the role of exercise in the management of osteoarthritis of the hip or knee-the MOVE consensus. Rheumatology. 2005;44:67-73.

14. Brody LT. Pain. In: Hall CM, Brody LT, editor. Therapeutic exercise: Moving Toward Function. $2^{\text {nd }}$ ed. Philadelphia:Lippincott Williams and Wilkins; 2005. p.185-204.

15. Kapandji IA. The physiology of the joints. Edinburgh: Churchill Livingstone; 1985. Sisto SA, Malanga G: Osteoarthritis and therapeutic exercise. Am J Phys Med Rehabil. 2006;85(Suppl):S69-S78.

16. Tulaar ABM. Peran terapi latihan penguatan otot pada osteoartritis sendi lutut: telaah pada metabolisme matriks tulang rawan sendi [dissertation]. Jakarta: Universitas Indonesia; 2004. 